\title{
First record of roving coral grouper Plectropomus pessuliferus (Fowler, 1904) from Saint Martin's Island, Bangladesh based on Morphology and DNA Barcoding
}

\author{
MD JAYEDUL ISLAM, SHARMIN AKTER, PROVAKOR SARKAR, MOHAMMAD \\ RASHED $^{1}$, IREEN PARVIN ${ }^{1}$ AND KAZI AHSAN HABIB ${ }^{1 *}$ \\ Aquatic Bioresource Research Lab (ABR Lab), Department of Fisheries Biology and Genetics \\ Sher-e-Bangla Agricultural University, Dhaka 1207, Bangladesh \\ ${ }^{1}$ Department of Fisheries Biology and Genetics, \\ Sher-e-Bangla Agricultural University, Dhaka 1207, Bangladesh \\ *Email: ahsan.sau@gmail.com; habibka@sau.edu.bd
}

\begin{abstract}
A new record of Plectropomus pessuliferus (Serranidae: Epinephelinae) was documented based on morphological characters and DNA barcoding. The species was collected during a regular survey for making an inventory of reef associated fishes in Saint Martin`s Island, Bangladesh. This is the first report of roving coral grouper from the marine waters of Bangladesh validated by morpho-meristic analysis and DNA barcoding. This is also the first report from the northern Bay of Bengal.
\end{abstract}

Keywords: Plectropomus pessuliferus, Bay of Bengal, Epinephelinae, DNA barcoding

\section{Introduction}

Serranidae is one of the diverse groups of commercially important fish commonly known as groupers, rock cods, hinds and sea basses. They have a high morphological diversity and spectacular color variations, and are inhabitants on reefs throughout shallow tropical seas (Heemstra 1991). The fish belonging to any of a number of genera in the subfamily Epinephelinae of the family Serranidae are known as groupers. Epinephelinae is the second largest subfamily of the family Serranidae comprising 188 valid species present in the world (Craig et al. 2011, Fricke et al. 2020). Among these, 110 species of grouper were recorded in the Indo-Pacific region (Randall and Heemstra 1991). A total of 15 species of four genera belonging to the subfamily Epinephelinae have been recorded from Bangladesh waters. Initially, Hossain (1970) listed eight species of Epinephelidae in Bangladesh. After that, other scholars added nine more species in the last one decade (Rahman et al. 2009, Thompson and Islam 2010, Habib et al. 2017). Plectropomus (Oken 1817) is a genus of colorful serranid fishes that belongs to the subfamily Epinephelinae. Members of this genus are typically associated with shallow water reefs in 3-147 m, and rarely caught by trawlers (Heemstra and Randall 1993). Saint Martin's Island is the only island in Bangladesh which contains coral colony and has a rich biodiversity, especially coral-associated fish species.

The present paper reports a new record of one more grouper species, Plectropomus pessuliferus (Fowler 1904) for the first time from Bangladesh. This species is known to be distributed in the Indo-Pacific from East Africa to Tonga, including Zanzibar, Chagos, 
Lacadives, St. Brandon's Shoals, Maldives, Sri Lanka, Andaman and Nicobar Island, Myanmar, Nazareth Bank, Sumatra, Fiji (Heemstra and Randall 1993, Rajan 2001, Randall et al. 2003, Rajan et al. 2013, Psomadakis et al. 2019, Frick et al. 2020). In the present study, the primary identification of Plectropomus pessuliferuswas carried out observing morphological characters. DNA barcoding was then used as a tool for further confirmation of the morphological identification of the species since DNA barcoding is one of the most reliable methods for the confirmation of species identity (Hebert et al. 2003).

\section{Material and Methods}

Sample collection: In March 2018, one individual of Plectropomus pessuliferus was collected during a survey on the diversity of coral associated fish from Saint Martin's Island, the southernmost part of Bangladesh facing the Bay of Bengal and located in Cox's Bazar district (Fig 1).

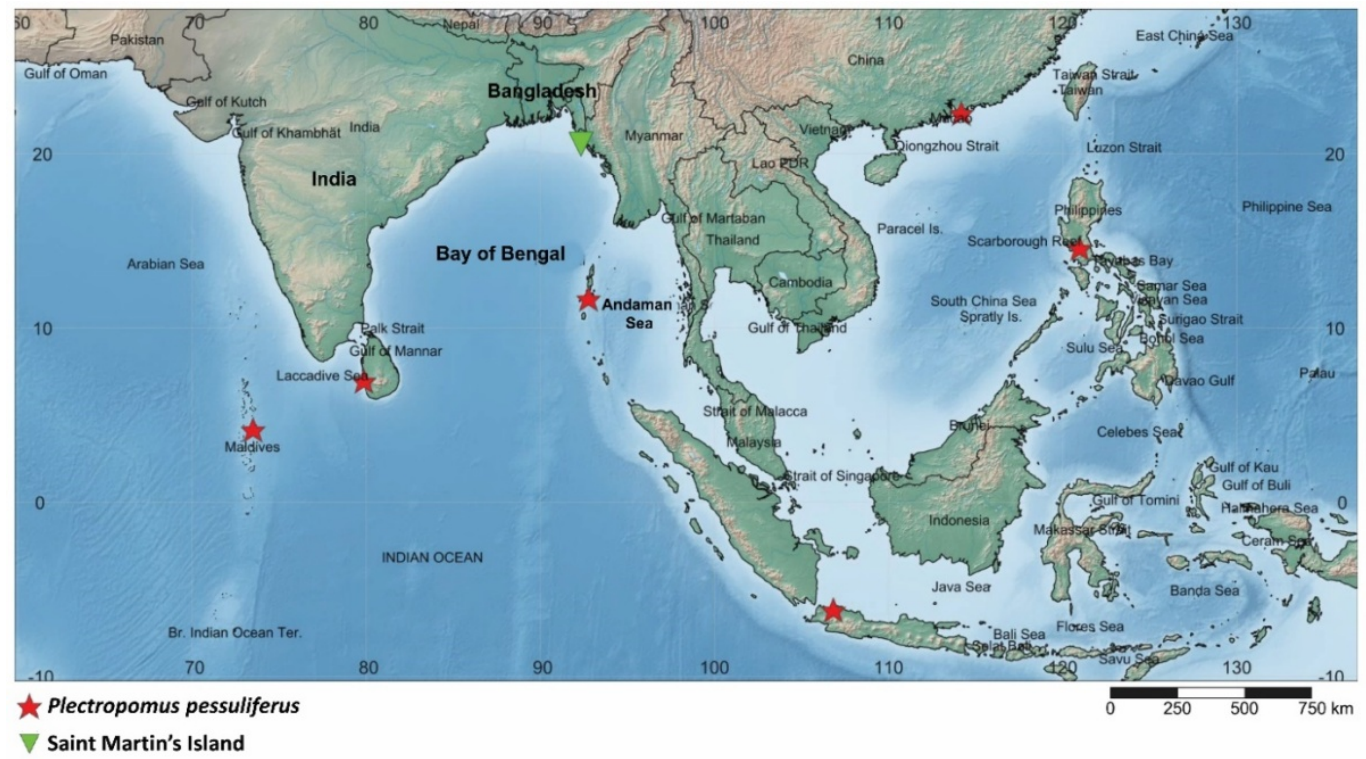

Fig. 1. Sampling location of Plectropomus pessuliferusin Saint Martin's Island, Bangladesh of the Northern Bay of Bengal $(\boldsymbol{\nabla})$; and previously reported locations $(\star)$.

Morphological analysis: For morphological identification, taxonomic keys used by Randall and Heemstra (1991), Heemstra and Randall (1993), Baldwin and Johnson (1994) and Elamin et al. (2011) were followed. Abbreviations: D1- First dorsal fin, P1- Pectoral fin, P2- Pelvic fin, AAnal fin, C- Caudal fin.

Molecular study: For molecular study, a piece of muscle tissue was collected and preserved in 95\% ethanol. Genomic DNA was extracted from preserved tissue sample using TIANamp Marine Animals DNA Kit (TIANGEN). The DNA barcode region of mitochondrial COI gene was amplified using the primer pair F1: 5'-TCAACCAACCACAAAGACATTGGCAC-3' and R1: 5'-TAGACTTCTGG GTGGCCAAAGAATCA-3' (Ward et al. 2005). Polymerase chain 
reaction (PCR) was performed in a $50 \mu l$ reaction mixture in a thermal cycler (2720 Thermal Cycler, Applied Biosystems). Thermal cycling conditions included an initial denaturation temperature of $95^{\circ} \mathrm{C}$ for 2 minutes and subsequently, 35 cycles consisting $94^{\circ} \mathrm{C}$ for 40 seconds for denaturation, $54^{\circ} \mathrm{C}$ for 40 seconds for annealing and $72^{\circ} \mathrm{C}$ for $1 \mathrm{~min}$ for extension. Lastly, $72{ }^{\circ} \mathrm{C}$ for $10 \mathrm{~min}$ was maintained for final extension. PCR products were examined by $1 \%$ agarose gel electrophoresis with a $100 \mathrm{bp}$ DNA ladder. Sequencing was conducted with the PCR primers by Sanger standard method in a normal automatic sequencer (Model 3730xI DNA analyzer. For molecular identification, we checked the DNA sequence using BLAST search engine provided by the National Center for Biotechnology Information (NCBI) and BOLD database. Finally, the obtained nucleotide sequence of COI barcode region was submitted to GenBank under the accession number of MK340678. For phylogenetic analysis, including the sequence of present study we used a total of five sequences of three species of the genus Plectropomus (i.e. P. pessuliferus, $P$. leopardus, $P$. maculatus) obtained from the BLAST search result in GenBank (Altschul et al. 1990). The Kimura-2 parameter (K2P) distance model (Kimura 1980) was used for calculating the genetic distance among the sequences using MEGA7. Aconfamiliar species Cephalopholis boenak (Bloch 1790) was used as an outgroup. Sequences were aligned and phylogenetic tree was constructed by Neighbor Joining (NJ) method using MEGA7 (Kumar et al., 2016). Robustness of the phylogenetic relationships was evaluated by bootstrap analysis with 10,000 replications (Felsenstein 1985). The examined specimen was deposited in the Aquatic Bioresource Research Lab., Department of Fisheries Biology and Genetics, Sher-e-Bangla Agricultural University, Dhaka, Bangladesh.

\section{Results}

Material examined: Specimen collected from Bangladesh: Cox`s Bazar, Saint Martin’s Island. Coordinate 20³4'50.1" N, 92²0'28.0" E (DMS) (Fig 1); Collected by Provakor Sarkar. 10 March 2018; one specimen; specimens voucher nos. F1803SM-43. GenBank Acession No. M340678. We identified our specimens as Plectropomus pessuliferus (Fowler 1904) (Roving coral grouper) based on morphological study.

Habitat: This fish was found in shallow waters of Saint Martin's Island.

Diagnostic Characters: D1 VIII, 11; P1 16; P2 I, 5; A III, 8; C 16. Body large, elongated and laterally compressed; its depth 10.3 in standard length (Fig 2). Ventral profile is more convex than ventral dorsal profile. Dorsal profile of head gently sloped. Mouth large, oblique, superior, and protractile. Preopercular edge serrated. Opercular flap present, opercle with three flat spines. Mouth gap large. Head large in comparison with body and numerous spot present (Fig. $2 \mathrm{a} \& b)$. Scale ctenoid and cover the whole body. Teeth canine and present in front of both the lower and upper jaw. Jaws large and lower jaw is larger than the upper jaw. Barble absent. Lateral line single, complete and curved. Eye large and completely dorsal in position. Dorsal fin single, large and continuous and starts at the middle of the pectoral fin. Anal-fin spines weak, first and second spines covered by skin. Caudal fin emarginated. 


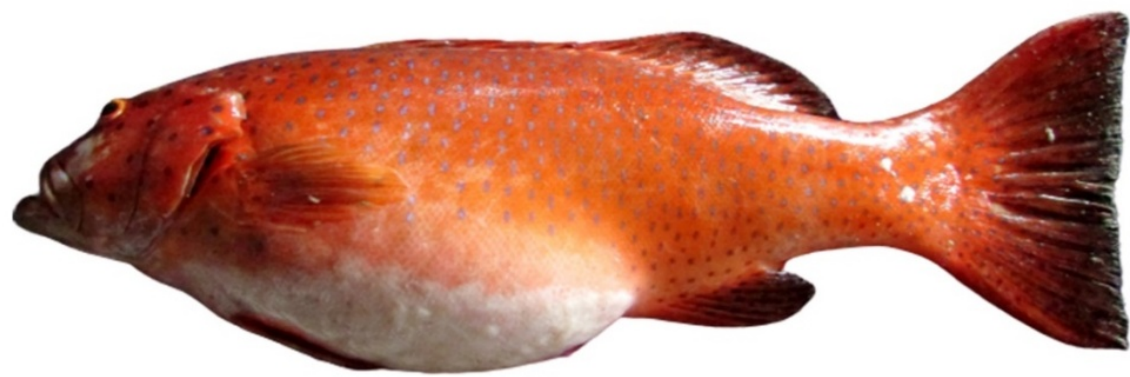

A

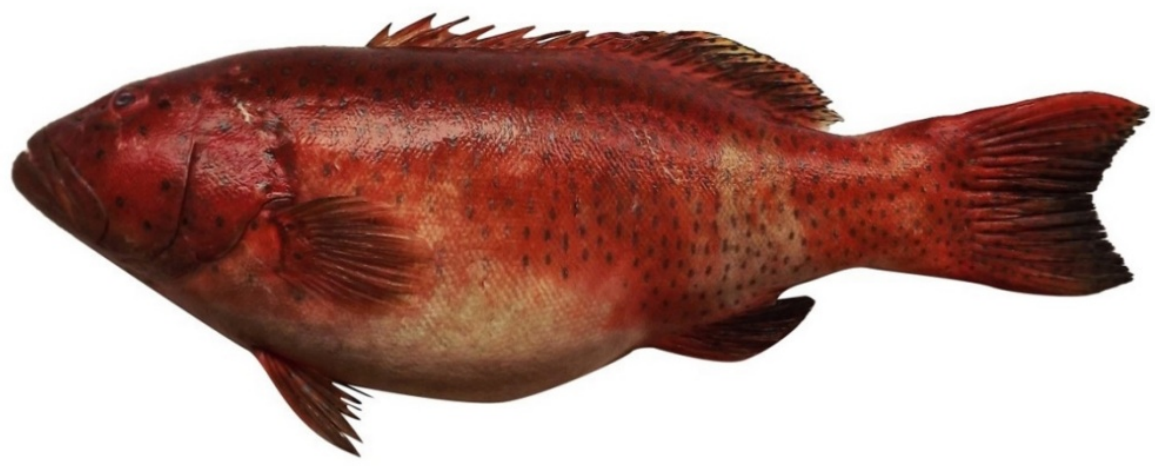

B

Fig. 2. A. Lateral view of fresh speciemen of Plectropomus pessuliferus, and B. Lateral view of preserved $P$. pessuliferus collected from Saint Martin's Island. SL $454.0 \mathrm{~mm}$.

Color: Coloration of body orange and ventral side is whitish. Numerous dark edged blue spot present along the body. Abundant blue spots found on all the fins. Head orange color; dorsal fin orange color and contains blue spot. Pectoral and pelvic fin somewhat grey in color. Anal and caudal fin dark orange color.

The morpho-meristic counts and measurements of the collected specimens of $P$. pessuliferus and its comparison with the records of Elamin et al. (2011) are given in Table I. 
MD JAYEDUL ISLAM et al.

Table I. Comparison of morphological and meristic characters of collected specimen $\boldsymbol{P}$. pessuliferus of the present study and the records of Elamin et al. (2011)

\begin{tabular}{|c|c|c|}
\hline Parameter & $\begin{array}{l}\text { P. pessuliferus } \\
\text { Present study }\end{array}$ & $\begin{array}{c}\text { P. pessuliferus } \\
\text { (Elamin et al. 2011) } \mathrm{n}=165\end{array}$ \\
\hline Total length (TL) & 552.0 & $569.0(326-900)$ \\
\hline Standard length (SL) & 454.0 & $462.9(267-750)$ \\
\hline \multicolumn{3}{|c|}{ Percentage of SL } \\
\hline Body depth (BD) & 44.7 & $35.90(33.7-38)$ \\
\hline Body width (BW) & 20.0 & \\
\hline Head length (HL) & 35.9 & $35.10(33.4-37.33)$ \\
\hline Inter-orbital length (IOL) & 6.83 & \\
\hline Pre-orbital length (PrOL) & 12.78 & \\
\hline Postorbital length (PoOL) & 20.48 & \\
\hline Eye diameter (ED) & 4.41 & $4.41(3.96-5.06)$ \\
\hline Snout length (SL) & 6.83 & $10.33(8.61-12.0)$ \\
\hline Caudal-peduncle length (CPL) & 16.74 & \\
\hline Dorsal-fin base length (DBL) & 43.61 & \\
\hline Pectoral-fin base length (P1BL) & 6.17 & \\
\hline Pelvic-fin base length (P2BL) & 5.73 & \\
\hline Anal-fin base length (ABL) & 15.64 & \\
\hline Caudal-fin base length (CPL) & 17.40 & \\
\hline Longest dorsal-fin length (DFL) & 11.23 & \\
\hline Longest pectoral-fin length (P1FL) & 17.62 & $15.45(14.99-16.10)$ \\
\hline Longest pelvic-fin length (P2FL) & 15.64 & $14.02(14.02-14.68)$ \\
\hline Longest anal-fin length (AFL) & 14.54 & \\
\hline \multirow[t]{3}{*}{ Caudal-peduncle depth (CPD) } & 13.66 & $11.15(11.16-12.0)$ \\
\hline & \multicolumn{2}{|c|}{ Meristic Study } \\
\hline & $\begin{array}{l}\text { P. pessuliferus } \\
\text { (Present study) }\end{array}$ & Heemstra and Randall (1993) \\
\hline Dorsal-fin spines & VIII & VII-VIII \\
\hline Dorsal-fin rays & 11 & $10-12$ \\
\hline Pectoral-fin rays & 16 & $15-16$ \\
\hline Pelvic-fin spine & I & \\
\hline Pelvic-fin rays & 5 & \\
\hline Anal-fin spines & III & III \\
\hline Anal-fin rays & 8 & 8 \\
\hline
\end{tabular}


Molecular identification: A clear nucleotide sequences of 611bp of mtDNA COI gene was obtained after removing ambiguous sequences near the primer ends and submitted to GenBank. No insertions, deletions or stop codons were observed in the sequence. The lack of stop codons is consistent with amplified sequence being functional mitochondrial COI sequence. To verify the result of morphological identification, our identified COI barcode region of $P$. pessuliferus specimen with other conspecific and congeneric species retrieved from the GenBank were compared. In the phylogeny, $P$. pessuliferus sequence of the present study (i.e. the Bay of Bengal) formed a single clade with two sequences of Australian individuals (Fig 3). No nucleotide difference was observed in these three sequences (i.e. single haplotype). Each of the three congeneric species of the genus Plectropomus made three separate clades in the neighbor joining tree. Genetic divergence was found $1.3 \%$ ( $\mathrm{SE} \pm 0.005$ ) between the $P$. pessuliferus of present study and phylogenetically the most closely related species Plectropomus leopardus reported from Malaysia. On the other hand, the genetic distance was calculated as $5.1 \%$ (SE \pm 0.009 ) between $P$. pessuliferus and Plectropomus maculatus of Malaysia in our study. Overall mean distance among the sequences of COI gene used in the study was $2.4 \%$.

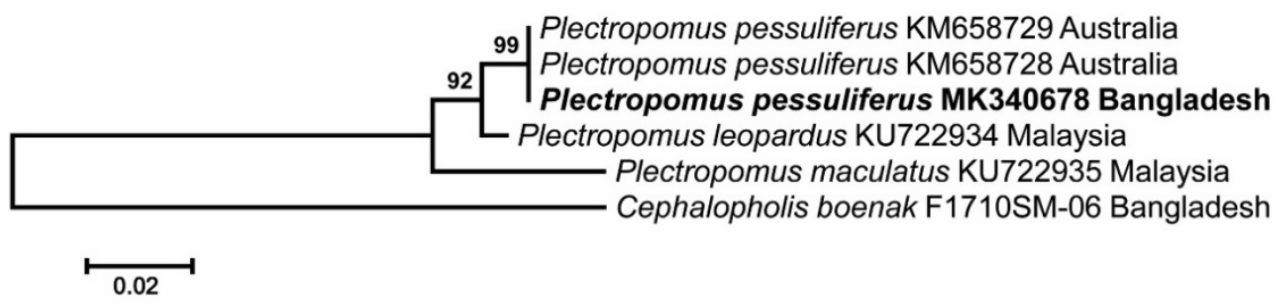

Fig. 3. Neighbor-joining tree for DNA barcode sequence (601 bp) of COI gene of Plectropomus pessuliferus. Accession number and the country of each sequence are given beside species name. Bootstrap support above $90 \%$ are shown above branches. Scale bar represents the substitution rate per site.

\section{Discussion}

A new record of Plectropomus pessuliferus (Serranidae: Epinephelinae) in Bangladesh is reported on the basis of morphological characters and DNA barcoding. During the survey, only one specimen was found which was then prepared for further analysis. Depending on the record of a single specimen for including a species in a region's or country's fish inventory was also carried out in other studies such as Vella et al. (2016), Sen et al. (2019) and De La Cruz et al. (2020). The members under subfamily Epinephelinae are usually identified by their colour pattern, morphological characters and size of the fins, the shape and relative size of the head and various parts of the head and body. Sometimes they exhibit different colors and morphological counts in the juvenile stage. The morphometric characters were counted, measured and photographed, then compared with the records of Elamin et al. (2011) and Heemstra and Randall (1993). All meristic characters are in agreement with previous record of this species (Table I). Although some morphological characters do not exactly similar to the range recorded by Elamin et al. (2011), the majorities of characters either overlap or span the range, which is reasonable given the differences in growth rate. 
COI sequencing is considered as an effective and reliable procedure in identifying species (Hebert et al. 2003). The query sequence showed a high identity (>99\%) with 2 sequences of Plectropomus pessuliferus deposited in the GenBank database (accession numbers: KM658728 and KM658729; Fig. 3). COI sequences of $P$. pessuliferus clustered into a monophyletic group that was clearly separated from other species of same genus. The results provide strong evidence for the species validity of $P$. pessuliferus by genetic study. The phylogentic analysis also showed that the sequences of $P$. pessuliferus was differentiated from other species of the same genus with the genetic distance ranged from $1.3 \%$ to $5.1 \%$. A list of the Epinephelid species currently known and their first report from Bangladesh are given in Table II. The list shows, 16 species under four genera (including the present study), namely Cephalopholis (3 species), Cromileptes (1 species), Epinephelus (10 species), Plectropomus (2 species) were recorded from Bangladesh which are relatively low in number compared to Indian waters. Rajan et al. (2017) recorded a total of 54 numbers of Epinephelids from Indian waters. However, India is a large country having several times larger maritime area than Bangladesh.

Table II. List of species from subfamily Epinepheninae in Bangladesh waters

\begin{tabular}{ll}
\hline Species Name & Reference \\
\hline Cephalopholis boenak (Bloch 1790) & Hussain 1969, Habib et al. 2017 \\
Cephalopholisf ormosa (Shaw 1812) & Rahman et al. 2009 \\
Cephalopholis sonnerati (Valenciennes 1828) & Hussain 1970 \\
Cromileptesa Itivelis (Valenciennes 1828) & Hussain 1970 \\
Epinephelus coioides (Hamilton 1822) & Habib et al. 2017 \\
Epinephelus erythrurus (Valenciennes 1828) & Habib et al. 2017 \\
Epinephelus hexagonatus (Forster 1801) & Tomascik 1997 \\
Epinephelus lanceolatus (Bloch 1790) & Hussain 1970 \\
Epinephelusl atifasciatus (Temminckand Schlegel 1842) & Hussain 1970 \\
Epinephelus malabaricus (Bloch and Schneider 1801) & Hussain 1970 \\
Epinephelus merra (Bloch 1793) & Hussain 1970 \\
Epinephelus morrhua (Valenciennes 1833) & Hussain 1970 \\
Epinephelus polyphekadion (Bleeker 1849) & Tomascik 1997 \\
Epinephelus quoyanus (Valenciennes 1830) & Molonyet al. 2006 \\
Plectropomus leopardus (Lacepède 1802) & Molonyet al. 2006 \\
Plectropomus pessuliferus (Fowler 1904) & Present study \\
\hline
\end{tabular}

The nearby areas of the Bay of Bengal from where the species $P$. pessuliferus was known to occur are Andaman and Nicobar Island, Srilanka and Myanmar but these species has no valid record from the northern part of the Bay of Bengal. This study confirms the presence of $P$. pessuliferus in the Saint Martin's Island of the north Bay of Bengal and indicates the possibility 
FIRST RECORD OF ROVING CORAL GROUPER PLECTROPOMUS PESSULIFERUS

of existence of more species of the genus Plectropomus in Bangladeshi marine water that have been overlooked in past surveys.

Acknowledgements: This study was supported by UNESCO/Korean Funds-in-Trust funded DRMREEF project coordinated by IOC Sub-Commission for the Western Pacific (WESTPAC).

\section{Literature Cited}

Altschul, S.F., W. Gish, W. Miller, E.W. Myers and D.J. Lipman, 1990. Basic local alignment search tool. J. Mol. Biol., 215 (3): 403-410.

Baldwin, C.C. and G.D. Johnson, 1994. FAO Species Catalogue. Vol. 16. Groupers of the World (Family Serranidae, Subfamily Epinephelinae). An Annotated and Illustrated Catalogue of the Grouper, Rockcod, Hind, Coral Grouper, and Lyretail Species Known to Date. Copeia,4: 1058- 1061.

Craig, M.T. and P.A. Hastings, 2007. A molecular phylogeny of the groupers of the subfamily Epinephelinae (Serranidae) with a revised classification of the Epinephelinae. Ichthyol. Res., 54: 1-17.

De La Cruz, J., R. Gonzalez, F. Garcia and V. Cota, 2020. First Record of aspecimen of the shortbill spear fish Tetrapturus angustirostris Tanaka, 1915 in the Pacific Coast of Mexico. Lat. Am. J. Aquat. Res., 47(4):

Elamin, S.M., M.A. Ambak, M.A. Samoilys, and M.E. Hamza, 2011. Some Morphometric Relationships of Coral Trouts Plectropomus pessuliferus and Plectropomus areolatus Inhabiting Sudanese Red Sea. Adv. Environ. Biol.,5(9): 2860-2865.

Felsenstein, J., 1985. Confidence limits on phylogenies: an approach using the bootstrap. Evolution, 39(4): 783-791.

Fricke, R., W.N. Eschmeyer and R. Van der Laan (eds.), 2020. Eschmeyer's Catalog of Fishes: Genera, Species, References. (http://researcharchive. calacademy.org/research/ ichthyology/catalog/fishcatmain.asp). Electronic version accessed 01 September 2020.

Habib, K.A., C.G. Kim, J. Oh, A.K. Neogi and Y.H. Lee, 2017. Aquatic Biodiversity of Sundarbans, Bangladesh. Korea Institute of Ocean Science and Technology (KIOST). 394 p.

Hebert, P.D.N., A. Cywinska, S.L. Ball and J.R. deWaard, 2003. Biological identification through DNA barcodes. Proceedings of the Royal Society of London. Series B: Biological Sciences, 270: 313-321.

Heemstra, P.C. and J.E. Randall, 1993. FAO species catalogue. Groupers of the world (Family Serranidae, Subfamily Epinephelinae) FAO Fisheries Synopsis. No. 125, Vol. 16. Rome, FAO. 382 p.

Heemstra, P.C., 1991. A taxonomic revision of the eastern Atlantic groupers (Pisces: Serranidae). Bol. Mus. Mun. Funchal., 43: 5-71.

Hussain, M.M., 1970. The Marine and Estuarine Fishes of North East part of the Bay of Bengal. Scientific Researches. East Regional Laboratories, Dhaka. 52 p.

Kimura, M., 1980. A simple method for estimating evolutionary rates of base substitutions through comparative studies of nucleotide sequences. J. Mol. Evol., 16(2): 111-120.

Kumar, S., G. Stecher and K. Tamura, 2016. MEGA7: Molecular Evolutionary Genetics Analysis Version 7.0 for Bigger Datasets. Mol. Biol. Evol.,33(7): 1870-1874. 
Molony, L., 2006. A National Project Professional Personnel. St Martin's Island ECA Conservation Management Plan. Coastal and Wetland Biodiversity Management Project, Department of Environment, Dhaka, Bangladesh.

Psomadakis, P.N., H. Thein, B.C. Russell and M.T. Tun, 2019. Field identification guide to the living marine resources of Myanmar. FAO Species Identification Guide for Fishery Purposes. FAO and MOALI, Rome. 694 p.

Rahman, A.K.A., S.M.H. Kabir, M. Ahmad, A.T.A. Ahmed, Z.U. Ahmed, Z.N.T. Begum, M.A. Hasan and M. Khondker, (eds.), 2009. Encyclopedia of Flora and Fauna of Bangladesh. Vol. 24. Marine Fishes. Asiatic Society of Bangladesh, Dhaka. 485 p.

Rajan, P.T., 2001. Field guide to grouper and snapper fishes of Andaman and Nicobar Islands. Zoological Survey of India. 103 p.

Rajan, P.T., C.R. Sreeraj and T.I.T.U.S. Immanuel, 2013. Fishes of Andaman Andaman and Nicobar Islands: a checklist. J Andaman Sci Assoc., 18(1): 47-87.

Rajan, P.T., S.S. Mishra and K.K. Bineesh, 2017. First records of two species of groupers, Cephalopholis nigripinnis and Epinephelus retouti (Perciformes: Epinephelidae) from India, with a note on Epinephelids from Andaman and Nicobar Islands. Rec. Zool. Surv. India, 117(3): 289-294.

Randall, J.E. and P.C. Heemstra, 1991. Revision of Indo-Pacific groupers (Perciformes: Serranidae: Epinephelinae), with descriptions of five new species. Indo-Pac. Fish., 20: 332.

Randall, J.E., J. Williams, D.G. Smith, M. Kulbicki, G.M. Tham, P. Labrosse, M. Kronen, E. Clua and B.S. Mann, 2003. Checklist of the shore and epipelagic fishes of Tonga. Atoll Res. Bull. Nos. 502.

Sen, S., G. Dash and S.A. Bharadiya, 2019. First Record of Longspine Grouper, Epinephelus longispinis (Kner, 1864) from Gujarat, North-West Coast of India. Thalassas: An Intl. J. Mar. Sc., 35: 287-289.

Thompson, P.M. and M.A. Islam, (eds.), 2010. Environmental Profile of St. Martin's Island, United Nations Development Programme, Dhaka. $150 \mathrm{p}$.

Tomascik, T., 1997. Management Plan for Resources of NarikelJinjira (St. Martin's Island) Final Report, National Conservation Strategy Implementation Project -1 Ministry of Environment and Forest, Government of Bangladesh. 125 p.

Vella, A., N. Vella and S. Agius Darmanin, 2016. The first record of the African sergeant, Abudefduf hoefleri (Perciformes: Pomacentridae), in the Mediterranean Sea. Mar. Biodivers. Rec., 9(15): 